\title{
TEORI HUKUM PROGRESIF DALAM MENYELESAIKAN SENGKETA BISNIS KEUANGAN SYARIAH
}

\author{
Nurhadi \\ Sekolah Tinggi Agama Islam (STAI) Al-Azhar Pekanbaru Riau \\ alhadijurnal@gmail.com
}

\begin{abstract}
The theory of progressive law in resolving Islamic financial disputes is very relevant to Hans Kelsen's thoughts on law as a concept in progressive legal development in order to perfect the function and effectiveness of law in society. In order to realize the balance or harmonization between das sollen and das sein. Completion of progressive legal theory still requires a filter from Hans Kelsen's opinion of the Theory of Pure Law. That the operation of the law can come out of the law, principles or norms ("rule breaking"). However, in its implementation still pay attention to existing laws. Understanding the law in a broad sense. The priority used as a guideline is legislation and customary law in accordance with the problems faced. Whereas in the implementation of progressive law there are still weaknesses in the human aspect, therefore the synergy of the application of law by taking into account the values that apply between the parties in this case can be extracted from the values contained in the principles of Pancasila and capabilities that cover 5 (five) ) intelligence, namely $S Q, A Q$, IQ, EQ and CQ. The solutions provided by progressive legal theory in resolving Islamic financial disputes are of two ways, namely litigation and non-litigation.
\end{abstract}

Keymords: Progressive Legal Theory, Dispute, Business, Islamic Finance.

Abstrak, Teori hukum progresif dalam menyelesaikan sengketa keuangan syariah sangat relevan dengan pemikiran Hans Kelsen tentang hukum sebagai suatu konsep dalam pembangunan hukum yang progresif yaitu dalam rangka menyempurnakan fungsi serta efektifitas hukum di masyarakat. Agar tewujud keseimbangan atau harmonisasi antara das sollen dan das sein. Penyempurnaan teori hukum progresif tetap memerlukan filter dari pendapat Hans Kelsen tentang Teori Hukum Murni. Bahwa bekerjanya hukum itu dapat keluar dari hukum, asas atau normanya ("rule breaking"). Namun dalam implementasinya tetap memperhatikan hukum yang sudah ada. Pengertian hukum dalam arti luas. Prioritas yang digunakan sedagai pedoman adalah peraturan perundang-undangan dan hukum adat sesuai dengan permasalahan yang dihadapi. Bahwa dalam implementasinya hukum progresif masih terdapat kelemahan dari aspek manusianya, oleh karena itu sinergi penerapan hukum dengan memperhatikan nilai yang berlaku di antara para pihak dalam hal ini dapat digali dari nilai-nilai yang terkandung dalam sila-sila Pancasila dan kemampuan yang mencakup 5 (lima) kecerdasan yaitu SQ, AQ, IQ, EQ dan CQ. Solusi yang diberikan teori hukum progresif dalam menyelesaian sengketa keuangan syariah ada dua cara, yaitu litigasi dan non litigasi.

KałaKunci: Teori Hukum Progresif, Sengketa, Bisnis, Keuangan Syariah. 


\section{Pendahuluan}

Peletak dasar teori hukum dalam kajian ilmu hukum dikenal pencetusnya Hans Kelsen (1881-1973). Majalah " Revue internationale de la theorie du droit International" dan "Zeitscrift fur Theorie des Rechts" sebagai buktinya, majalah tersebut didirikantahun 1926, maka saat itu istilah yang digunakan "teori hukum" dan bukan" allgemeine Rechtslehre". Alasan nama "teori hukum" dipakai dikarenakan untuk memberikan batasan agar tidak terjadi perdebatan yang memunculkan ketidakpastian tentang "keadilan", "kelayakan" dan "hukum kodrat". Dengan perkataan lain, teori hukum dilihat sebagai "teori hukum positif". ${ }^{1}$ Tokoh positivisme hukum yang bernama Hans Kelsen, menurutnya hukum merupakan sistem norma, yaitu suatu sistem yang berdasarkan atas keharusan-keharusan (apa yang semestinya atau das sollen). Menurutnya juga, norma bahagian dari hasil filsafat pemikiran manusia yang bersifat deliberatif. Norma akan tetap jadi norma jika hal itu di inginkan, landasan dasarnya adalah moralitas lingkungan maupun nilai-nilai yang baik. Satu-satunya hukum yang benar bagi Hans Kelsen adalah hukum positif (yang bermakna what the law it is), bukan hukum alam. ${ }^{2}$

Suatu teori yang "murni" (the pure theory of law) apabila terbebas dari unsur-unsur lain dar beberapa jenis teori tradisional, teori murni juga tidak bergantung pada analisis moralitas dan fakta-fakta relevan. Menurut Hans Kalsen pada saat itu nilai-nilai filosofi hukum yang berlaku sudah terkontaminasi dengan ideologi politik dan moralitas, juga mengalami reduksi disebabkan ilmu pengetahuan yang ada. Sementara seharusnya hukum itu mesti murni dari unsur-unsur diluar yang bukan yuridis. Model inilah teori hukum murni yang dikemukakan Hans Kelsen sebagai prinsip metodologisnya. Setiap hukum yang berlaku seharusnya suci dari hal-hal yang non yuridis, misalnya unsur sosiologis, politis, historis, bahkan etis. Menurut Hans Kelsen dalam memahami pure theory of law-nya sebagai teori kognisi hukum (teori pengetahuan hukum). Kalsen juga sering mengulang-ulangnya bahwa satu-satunya tujuan pure theory of law adalah kognitif (pengetahuan yang objektif), ${ }^{3}$ maka hal ini yang menjadikan Hans Kalsen sebagai pemikir positivism hukum dikarenakan ke konsitenannya dalam teori hukum murni. ${ }^{4}$

Teori Hukum Murni (The Pure Theory of Law) sebagai teori hukum positif, namun tidak membicarakan hukum positif yang berlaku dalam sistem hukum tertentu, melainkan hanya teori hukum umum. Pemaparan Teori Hukum Murni Hans Kelsen bertujuan dalam menjelaskan hakikat hukum dan metode pembuatan hukum, dan tidak dalam memaparkan hukum semestinya (what the law ought to be) ataupun cara terbaik hukum diciptakan. Teori

1 SudiknoMertokusumo, "Teori Hukum", Yogyakarta: Cahaya Atma Pustaka, 2012, hlm. 83.

2 Hans Kelsen A, "Pengantar Teori Hukum", Penerjemah: Siwi Purwadi, Bandung: Nusa Media, 2015, hlm. 23-25.

3 Hans Kelsen B, "Teori Hukum Murni", Penerjemah: Raisul Muttaqin, Bandung: Nusa Media, 2015, hlm. 3.

4 Ibid. 
Hukum Murni Hans Kelsen merupakan teori ilmu hukum (legal science) dan bukan soal kebijakan hukum (legal policy). ${ }^{5}$

Abad ke 21 ini merupakan abad digital sehingga memerlukan digital thinking. Manusia patut menyadari pemberlakuan undang-undang negara, bukan hanya kepastian hukum namun harus mencapai keadilan hukum di masyarakat juga kemanfaatan secara universal. Hukum yang ada tidak hidup diruang hampa namun hidup di alam manusia yang bersifat dinamis, karenanya perlu pemberlakuan undang-undang negara yang merupakan kebutuhan manusia yang memerlukan informasi dan pelayanan publik. Maka konsekuensinya mesto disiapkan infrastruktur yang dapat mendukung program serta sosialisasi, bukan hanya mengandalkan fiksi hukum sebagai ciri khusus teori positivisme. ${ }^{6}$

Situasi semacam itu memerlukan Sumber Daya Manusia (SDM) yang profesional agar pemberlakukan undang-undang negara sesuai harapan. Maka SDM yang berbasis spiritualitas, suatu keniscayaan, dengan cara rekrutman SDM yang berbasis moralitas yaitu pendidikan yang berstandar nasional dan internasional, karena SDM membutuhkan semangat serta latar belakang tujuan diberlakukan undang-undang tersebut. Perlunya pergeseran paradigma penegakan hukum, Sinzheimer mengatakan, hukum itu tidak bergerak di ruang hampa atau abstrak, akan tetapi berada dalam tatanan sosial masyarakat, sehingga ada efekefek yang dari keberlakuan hukum itu. ${ }^{7}$

Masalah efiesiensi suatu peraturan hukum sangat penting, juga cara pandang dan pola berpikirnya, perlu meninjau hubungan hukum dengan faktor-faktor serta kekuatan-kekuatan sosial diluarnya. Menurut Robert B. Seidman, bahwa setiap undang-undang, sekali dikeluarkan akan berubah, baik melalui perubahan normal maupun melalui cara-cara yang ditempuh birokrasi ketika bertindak dalam bidang politik, ekonomi, sosial dan lainnya. ${ }^{8}$

Perkembangan masyarakat dan susunannya semakin kompleks, mengkehendaki peraturan hukum yang mengikuti perkembangan masyarakat. Seluruh aspek kehidupan di masa sekarang telah ada aturan dalam perundang-undangan. Hukum memegang peran penting dalam kerangka kehidupan social masyarakat modern. ${ }^{9}$

Pergeseran adanya peran hukum (hukum negara), maka paradigma kekuasaan yang dipergunkan dalam penegakan hukum di Indonesia, perlu ada perubahan atau diamandemen dengan adanya penegakan hukum berbasis paradigma moral. Paradigma moral ideal harus

5 Adji Samekto, "Hukum dalam Lintasan Sejarah", Bandar Lampung: Indepth Publishing, 2013, hlm. 49-52.

${ }^{6}$ Hans Kelsen B, Op. Cit, hlm. 5-9.

7 Ibid, hlm. 27-29.

${ }^{8}$ Robert B. Seidman dalam Turiman, "Memahami Hukum Progresif Prof. Satjipto Rahardjo Dalam Paradigma "Thawaf" (Sebuah Kontemplasi Bagaimana Mewujudkan Teori Hukum Yang Membumi/Grouded Theory Meng-Indonesia", Artikel, Semarang: Program Doktor Ilmu Hukum UNDIP, 2010, hlm. 34.

9 Esmi Warassih, "Pranata Hukum Sebuah Telaah Sosiologis", Semarang: PT. Suryandaru Utama, 2015, hlm. 21 
mempunyai seperangkat nilai sebagai egalitarian, demokratis, pluralistis, dan profesional dalam membangun masyarakat madani (civil society). Perubahan paradigma sangat penting diupayakan untuk memulihkan dan mengembalikan otentisitas hukum sebagai sarana untuk memberikan kebahagiaan semua orang". ${ }^{10}$

Satjipto Rahardjo dalam pemikiranya selalu menaruh keprihatinan tentang orientasi hukum dalam mengantarkan kebahagiaan, bukan sebaliknya. Orientasi pemikiran hukum seperti itu, dalam Pembukaan Undang-Undang Dasar (UUD) 1945, secara tektual dirumuskan: “.....untuk membentuk suatu pemerintah negara Indonesia yang melindungi segenap bangsa Indonesia dan seluruh tumpah darah Indonesia dan untuk memajukan kesejahteraan umum, mencerdaskan kehidupan bangsa, dan ikut melaksanakan ketertiban dunia yang berdasarkan kemerdekaan, perdamaian abadi dan keadilan sosial....".

Sesuai uraian di atas dan adanya perkembangan ilmu pengetahuan dan teknologi pada era global, serta berkembangnya "paradigma" sebagai bagian dari perkembangan filsafat ilmu, nampak adanya suatu kebutuhan untuk menguji relevansi pemikiran Hans Kelsen tentang hukum pembangunan dan konsep hukum progresif Satjipto Rahardjo.

Salah satu perkara sengketa ekonomi syariah yang terdaftar di Pengadilan Agama Kota Tasikmalaya pada Tanggal 01 Februari 2016 dengan Nomor register 175/ Pdt.G/2016/PA.Tmk Tentang gugatan wanprestasi. Bank bertindak sebagai Penggugat melawan Tergugat I dan Tergugat II. Adapun duduk perkaranya, bahwa antara Penggugat dan Tergugat pada Tanggal 25 April 2014, telah sepakat dan setuju melakukan perjanjian Pembiayaan Murabahah dengan memberikan modal pembiayaan kepada Tergugat I sebesar Rp. 64.400.000,-. Dalam akad No. 2790/PEM/MBA/04/2014. Tergugat I diwajibkan melakukan pembayaran pokok dan margin sebesar Rp. 1.788.889,-/ bulan, setelah perjanjian berjalan selama 7 bulan, Tergugat telah lalai membayar kewajiban utanngnya, sejak Tanggal 25 Desember 2014. Penggugat telah mengirimkan somasi atau surat pemberitahuan kepada Tergugat I dan Tergugat II untuk segera menyelesaikan kewajibannya kepada penggugat, namun tetap tidak melakukan kewajibannya.akibat perbuatan wanprestasi Tergugat I, Penggugat menghadapi kerugian materil sebesar 51.717.777,- dan kerugian immateril yang diperkirakan dengan uang sejumlah 100.000.000,-. Sehingga Penggugat mengajukan perkara ini ke Pengadilan Agama Kota Tasikmalaya. ${ }^{12}$

Adapun petitum dari perkara ini adalah:

1) Menerima dan mengabulkan gugatan Penggugat untuk seluruhnya;

2) Menyatakan demi hukum Perjanjian Pembiayaan Al-Murabahah No. 2790/PEM/MBA/04/2014 yang disepakati Penggugat dan Tergugat I adalah sah dan mmpunyai kekuatan hukum;

10 Ibid.

11 Turiman, "Memahami Hukum Progresif Prof. Satjipto Rahardjo dalam Paradigma "Thawaf" (Sebuah Kontemplasi Bagaimana Mewujudkan Teori Hukum Yang Membumi/Grouded Theory Meng-Indo-nesia", Jurnal Semarang: Program Doktor Ilmu Hukum UNDIP, 2010, hlm. 33-35.

${ }^{12}$ Salinan Kasus Sengketa Keuangan Syariah Pengadilan Agama Tasikmalaya. 
$\begin{array}{lll}\text { Lurnaf } \text { fukum }_{\text {Kum }} & \text { P-ISSN } & : 2615-3416 \\ \text { Samudra Keadilan } & \text { E-ISSN } & : 2615-7845\end{array}$

Volume 14, Nomor 2, Juli-Desember 2019

3) Menyatakan segala akta-akta yang berkaitan dengan pernyataan dan jaminan untuk kepentingan Perjanjian Pembiayaan Murabahah a quo adalah sah dan mempunyai kekuatan hukum;

4) Menyatakan Para Tergugat telah melakukan perbuatan ingkar janji (wanprestasi);

5) Menghukum Para Tergugat secara tanggung renteng untuk melunasi seluruh kewajiban Tergugat I kepada Penggugat yaitu sebesar Rp. 51.717.777,-

6) Menghukum Para Tergugat (Tergugat II) untuk menyerahkan cessie gaji dengan angsuran perbulan Rp. 1.788.889,- atas nama Tergugat I kepada Penggugat.

7) Menghukum Para Tergugat menurut hukum untuk membayar uang paksa sebesar Rp. 1.000.000,- untuk setiap harinya, apabila para Tergugat lalai memenuhi isi putusan ini.

8) Menyatakan sah dan berharga sita lebih dulu yang telah diletakkan atas barang-barang yang bersangkutan : tanah dan bangunan, yang terletak di Jalan Permata Indah 3 No.9 Rt.07/03, Kelurahan tugujaya, Kecamatan Cihideung, Kota Tasikmalaya.

9) Menyatakan putusan ini dapat dilaksanakan terlebih dahulu meskipun ada bantahan (verzet), banding atau Kasasi.

10) Menghukum Para Tergugat untuk membayar biaya perkara yang timbul dalam perkara ini

Adapun isi dari amar putusannya adalah sebagai berikut:

1) Menyatakan gugatan Penggugat tidak dapat diterima

2) Menghukum Penggugat untuk membayar biaya perkara ini sejumlah Rp. 381.000,-. Petimbangan hukum hakim dalam perkara ini, dengan mengambil alih pendapat para pakar hukum bahwa gugatan pada pokoknya harus memuat syarat formil : identitas Para Pihak, posita dan petitum. ${ }^{13}$ Gugatan harus dibuat dengan cermat, terang, singkat, padat, dan jelas. Dalam perkara ini pertimbangan hakim dalam hal identitas alamat Terguat I yang sudah secara patut dan resmi dipanggil, menurut Aparat Kelurahan sudah pindah, namun dalam gugatan alamat Tergugat tidak dirubah sama Penggugat sampai sidang ketiga, Tergugat I tidak hadir juga. Sehingga Hakim berkesimpulan bahwa gugatan Penggugat telah melanggar salah satu syarat formil gugatan yang mengakibatkan gugatan tidak jelas (obscuur libel) dan cacat formil dan harus dinyatakan tidak dapat diterima (Niet Onvanklijke Verklaard)

Misalnya UU 8/1995 dan Fatwa DSN MUI yang dibentuk untuk mengatur pasar modal syariah, belum secara spesifik mengatur soal penyelesaian sengketa pasar modal syariah, baik secara litigasi maupun non litigasi. Dengan demikian, terdapat kekosongan hukum (leemten in het recht) dalam regulasi pasar modal syariah yang menimbulkan tidak adanya kepastian hukum. Dengan menggunakan prinsip penemuan hukum (rechtsvinding), melalui metode

13 Menurut Prof Dr. Sudikno Mertokusumo dalam bukunya " Hukum Acara Perdata Indonesia" menyatakan bahwa gugatan pada pokoknya harus memuat identitas Para Pihak, posita dan petitum. Menurut Prof. Dr. H. Abdul Manan, S.H., S.Ip., M.Hum. dalam bukunya " Penerapan Hukum Acara Perdata di Lingkungan Peradilan Agama", bahwa gugatan harus dibuat secara cermat, terang, singkat, padat dan tidak obscuur libel (kabur/tidak jelas).begitu juga menurut M. Yahya Harahap, S.H. dalam bukunya "Beberapa Permasalahan Hukum Acara pada Pengadilan Agama, bahwa gugatan harus memenuhi syarat formil dan tidak boleh terabaikan salah satu pun syarat formil 
interpretasi sistematis dan logis, maka kekosongan hukum penyelesaian sengketa pasar modal syariah dirujuk kepada UU 3/2006 yang telah diubah menjadi UU 50/2009. Berdasarkan Pasal 49 huruf (i) UU 3/2006 penyelesaian sengketa pasar modal syariah secara litigasi dilakukan oleh Pengadilan Agama. Adapun penyelesaian sengketa pasar modal syariah secara nonlitigasi dapat dilakukan melalui Arbitrase atau Alternatif Penyelesaian Sengketa yang meliputi konsultasi, negosiasi, mediasi, konsiliasi atau penilaian ahli sebagaimana diatur UU 30/1999. Oleh karena pasar modal syariah berjalan berdasarkan prinsip syariah, maka lembaga arbitrase yang digunakan adalah Badan Arbitrase Syariah Nasional (BASYARNAS). Dalam rangka mendukung penguatan kerangka hukum dalam pengembangan pasar modal syariah, perlu dibentuk satu regulasi khusus berupa undangundang pasar modal syariah yang di dalamnya mengatur secara komprehensif dari ketentuan umum hingga penyelesaian sengketa dengan memberikan kewenangan kepada Pengadilan Agama dalam penyelesaian sengketa secara litigasi. Dalam regulasi tersebut juga diatur mengenai penyelesaian sengketa pasar modal syariah secara non-litigasi dengan memberikan kewenangan kepada Badan Arbitrase Syariah Nasional (BASYARNAS) sebagai lembaga penyelesai sengketanya. Dengan demikian, persoalan kekosongan hukum mengenai penyelesaian sengketa pasar modal syariah mendapat kepastian hukum.

Sesuai dengan latar belakang diatas, maka yang menjadi pembahasan dalam artikel ini adalah:

1) Bagaimana kedudukan teori hukum progresif dalam penyelesaian sengketa keuangan syariah?

2) Bagaimanakah perbandingan analisa hukum progresif teori hukum Hans Kelsen dan Satjipto Raharjo dalam penyelesaian sengketa keuangan Syariah?

3) Bagaimanakah solusi teori hukum progresif Hans Kelsen dan Satjipto Raharjo dalam penyelesaian sengketa keuangan Syariah?

\section{Pembahasan}

\section{Aplikasi Teori Hukum Progresif Hans Kelsen dalam Sengketa Keuangan Syariah}

Di dalam melakukan analisis terhadap teori Hans Kelsen ini akan diimplementasikan dalam realitas hubungan hukum antara Konsep Hukum Hans Kelsen denga teori murninya (the pure theory of law) bebas dari unsur-unsur asing pada kedua jenis teori tradisional, teori tersebut tidak tergantung pada pertimbangan moralitas dan norma dan fakta aktual terkini. Pendapat Hans Kelsen bahwa filosofis hukum yang berlaku dikatakan telah terkontaminasi dengan ideologi politik dan moralitas disatu sisi, juga telah mengalami reduksi terhadap ilmu 
Volume 14, Nomor 2, Juli-Desember 2019

pengetahuan. ${ }^{14}$ Hukum harus murni dari elemen asing yang tidak yuridis. Prinsip metodologis dasar dari konsep Hans Kelsen tentang konsep hukum murninya. ${ }^{15}$ Kelsen memahami pure theory of law-nya sebagai teori kognisi hukum (teori pengetahuan). ${ }^{16}$

Teori Hans Kelsen sebagaimana telah disebutkan di atas jika diterapkan dalam realitasnya maka tidak sesuai lagi dengan perkembangan fakta dan kebutuhan masyarakat. Aspek keadilan yang diharapkan masyarakat tidak dapat terwujud. Karena pemahaman masyarakat tentang hukum tidak hanya "hukum" itu sendiri. Masyarakat selama ini memahami sebagai peraturan perundang-undangan saja. Bahwa dalam realitasnya hukum itu berinteraksi juga dengan perilaku masyarakatnya, dalam hal ini manusianya. Ada aspek moral dan etika yang melingkupi hokum dalam implementasi dan penyelesaian masalahnya. Misalnya dalam hubungan hukum antara bank syariah dan nasabah dalam penyelesaian sengketa jaminan hak tanggungan. Berdasarkan ketentuan dalam Pasal 10 Undang-undang Hak Tanggungan bahwa lahirnya jaminan hak tanggungan adalah setelah didaftarkan ke Badan Pertanahan Nasional (BPN). Jika tidak didaftarkan maka konsekuensi yuridisnya jaminan hak tanggungan itu tidak dapat dieksekusi. Bank Syariah tidak dapat menjual objek jaminan hak tanggungan kecuali memperoleh kuasa jual dari nasabah bank syariah. ${ }^{17}$

Berdasarkan fakta yang ada di lapangan, ada bank syariah yang tidak mendaftarkan jaminan hak tanggungan tersebut hingga menimbulkan permasalahan antara bank syariah dan nasabah yang menimbulkan kerugian baik materiil maupun imateriil bagi nasabah bank syariah. Berdasarkan fakta tersebut pelanggaran atas hukum yang seharusnya dijalankan telah menimbulkan ketidakadilan. Di sisi yang lain bagi nasabah yang seharusnya melaksanakan kewajibannya namun ada pula yang tidak memenuhi isi perjanjian dengan tidak melakukan pembayaran tepat pada waktunya dan tidak beritikad baik, untuk memberitahukan perubahan jangka waktu pembayarannya. Dalam hal ini nasabah telah melakukan wanprestasi, dan telah melakukan pelanggaran moral dalam hubungan hukumnya dengan bank syariah. ${ }^{18}$

Contoh kasus di atas menunjukkan adanya ketidaksesuaian Teori Hans Kelsen untuk menyelesaikan kasus yang dialami dalam hubungan hukum antara bank syariah dan nasabah. Karena selain perjanjian (akad syariah) sebagai hukumnya, dalam implementasinya ada juga perilaku yang terjadi antara pihak bank syariah dan nasabah dalam penyelesaian permasalahan yang terjadi. Juga terdapat pelanggaran etika dan moral yang melingkupinya. ${ }^{19}$

14 Anonimus, "Teori Hukum Murni (The Pure Theory Of Law)", http://mknunsri.blogspot.com/2010/03/teori-hukum-murni-pure-theory-of-law.html, diakses tanggal 29 November 2015. Anonim-MKN UNISRI, 2015: t.hlm.diakses 21 Januari 2019.

15 Darji Darmodiharjo dan Shidarta, "Pokok-Pokok Filsafat Hukum", Jakarta: Gramedia Pustaka Utama, 2014, hlm. 115.

${ }^{16}$ Hans Kelsen B, Op. Cit,.., hlm. 3.

17 Hans Kelsen A, Op. Cit, hlm. 31

${ }^{18}$ Hans Kelsen B, Op. Cit, hlm. 37

19 Ibid. 
Lurnas Ffukum P-ISSN : 2615-3416

Samudra Keadilan

E-ISSN : 2615-7845

Volume 14, Nomor 2, Juli-Desember 2019

\section{Aplikasi Teori Hukum Progresif Satjipto Rahardjo dalam Penyelesaian Sengketa Keuangan Syariah}

Dalam menganalisis konsep Satjipto Rahardjo, seorang mahaguru ilmu sosiologi hukum di Indonesia, beliau yang mengkonstruksikan masyarakat adalah tatanan normatif yang tercipta dari sebuah proses interaksi antar sosial dan kearifan nilai sosial. Ada sembilan konsep Teori Hukum Progresif yang beliau tawarkan, yaitu: ${ }^{20}$

1) Hukum pada dasarnya menolak tradisi analytical jurisprudence atau rechtsdogmatiek dan bermacam-macam pemahaman aliran misalnya legal realisme, freirechtslehre, sociological jurisprudence, interresenjuris-prudenz seperti di Jerman, teori hukum alam dan critical legal studies;

2) Hukum pada dasarnya menolak pemahaman bahwa ketertiban (order) hanya berlaku pada institusi kenegaraan dan kekuasaan;

3) Hukum progresif pada dasarnya ditujukan dalam melindungi rakyat menuju kepada keadilan ideal dalam hukum;

4) Hukum pada dasarnya menolak teknologi sebagai landasan teori hukum karena tidak bernurani;

5) Hukum pada dasarnya suatu institusi yang bertujuan mengantarkan manusia kepada kehidupan yang adil, sejahtera dan kebahagiaan;

6) Hukum progresif pada dasarnya hukum yang pro rakyat dan hukum yang pro keadilan;

7) Dasar asumsi dalam hukum progresif adalah hukum untuk manusia, untuk masyarakat yang lebih luas dan lebih besar. Jika ada masalah pelik danbesar, maka hukumlah yang ditinjau dan diperbaiki, bukan sebaliknya.

8) Hukum bukanlah suatu institusi yang bersifat absolut dan final melainkan selalu bergantung pada manusia melihat dan menggunakannya.

9) Hukum dalam prosesnya selalu berada didepan (Law as a process, Law in the making). Dalam hal ini cara berhukum secara progresif memerlukan empati dan keberanian. Cara berhukum secara progresif memberikan porsi yang cukup banyak untuk membuat kreatifitas-kreatifitas baru yang tentunya berdasarkan atas keadilan dan kebutuhan masyarakat akan hukum tersebut.

Kesembilan konsep teori hukum progresif dari Satjipto Rahardjo tersebut di atas jika diterapkan satu-persatu dalam fakta di masyarakat, tentunya dirasakan yang dapat memberikan rasa keadilan dan memberikan jawaban atas permasalahan yang ada di masyarakat. Bekerjanya hokum dimasyarakat sangat bisa dirasakan dan memenuhi rasa keadilan yang diperlukan. ${ }^{21}$

${ }^{20}$ Robert B. Seidman dalam Turiman, "Memahami Hukum Progresif Prof. Satjipto Rahardjo dalam Paradigma "Thawaf" (Sebuah Kontemplasi Bagaimana Mewujudkan Teori Hukum Yang Membumi/Grouded Theory Meng-Indonesia", Jurnal, Semarang: Program Doktor Ilmu Hukum UNDIP, 2010, hlm. 12.

21 Ibid. 
Lurnas Fukum

Samudra Keadilan

Volume 14, Nomor 2, Juli-Desember 2019
P-ISSN : :2615-3416

E-ISSN : 2615-7845

Penegak hukum yang menentukan isi muatan undang-undang tentu saja secara aktif akan melibatkan empati, nilai-nilai, keberanian dan lain-lain. Gagasan teori progresif hukum adalah manusia. Menurut Satjipto Rahardjo bahwa hukum progresif adalah menguji ambang batas kekuatan hukum dalam menegakkan keadilan di masyarakat. ${ }^{22}$ Pendapat Noer Jameel, bahwa keadilan itu yang diciptakan bukan keadilan menurut teks undang-undang akan tetapi keadilan yang sebenarnya muncul dari tingkat kecerdasan serta kearifan berfikir penegak hukum dalam hal ini seorang hakim. ${ }^{23}$

Berdasarkan 9 (Sembilan) konsep tersebut di atas, hukum progresif hendak mengembalikan hukum kepada jalur yang seharusnya (on the right track) dan untuk itulah Satjipto Rahardjo berpendapat diperlukan terobosan-terobosan hukum (legal breakthrough, bukan legal breaking) atau terobosan besar dalam proses pembentukan dan penegakan hukum. Dalam prakteknya, penerapan hukum progresif terdapat kelemahan. Para penegak hukum yang juga manusia dalam menerapkan hukum progresif telah banyak menimbulkan kerugian pula karena tidak ada kontrol atau pengendali yang dapat digunakan sebagai indikator atau pedoman. ${ }^{24}$

Para penegak hukum dan aparat penegak hukum dalam prakteknya kemudian lepas control dan menggunakan celah yang untuk memenangkan kemauan atau kehendaknya tanpa memperhatikan nurani. Contoh yang terjadi pada praktek penyelesaian sengketa perbankan syariah pasca berlakunya Undang-undang Nomor 21 Tahun 2008 (selanjutnya ditulis UU Perbankan Syariah). Pihak Bank Syariah dengan mendasarkan pada bagian penjelasan Pasal 55 UU Perbankan Syariah telah menetapkan secara sepihak tempat penyelesaian sengketa tanpa memperhatikan rasa keadilan, nilai rasa dan jiwa dari pihak nasabah bank syariah yang menginginkan penerapan prinsip syariah dalam melaksanakan transaksi ekonominya. Dalam hal ini pihak nasabah berkehendak agar tempat penyelesaian sengketa melalui Pengadilan Agama atau Basyarnas namun pihak bank syariah menghendaki tempat penyelesaian di Pengadilan Negeri. ${ }^{25}$

Permasalahan yang terjadi dalam operasionalisasi bank syariah pada akhirnya mendorong masyarakat yang dirugikan melakukan judicial review atas UU Perbankan Syariah tersebut dan akhirnya pada tanggal 29 Agustus 2013 telah ada Keputusan Mahkamah

22 Satjipto Rahardjo, "Hukum Progresif, Aksi, Bukan Teks", Kumpulan Tulisan Pada Ulang Tahun ke-40 Prof. Dr. Zuhdan Arif Fakrullah, disusunoleh Satya Arinantodan Ninuk Triyanti, Memahami Hukum dari Konstruksi sampai Implementasi, Jakarta: Rajawali Pers, 2015, hlm. 3-5.

23 Noer Jameel, "Hakim Progresif, Mengurai Benang Kusut Ketidak tertiban Masyarakat di Indonesia", Academia.edu. 2014.

${ }^{24}$ Satjipto Rahardjo, Op. Cit, hlm. 5-9.

${ }^{25}$ Pasal 55 UU No. 21 Th 2008 dan penjelasannya, Pasal 39 UU No. 30 Th 1999, UU No. 4 Th. 1996, UU No. 50 Th. 2009 à Statute Aproach à Hubungan Keperdataan à Teori Perjanjian dan Hukum Acara, Hukum Acara Peradilan Agama, Putusan Mahkamah Konstitusi Nomor 93/PUUX/2012 -à Pollitik Hukum àTeori Politik Hukum, Putusan Hakim Pengadilan Agama dan Hakim Pengadilan Negeri terkait dengan Penyelesaian Sengketa Jaminan Hak Tanggungan. 
Konstitusi Nomor 93/PUU-X/2012. Berdasarkan kasus dalam praktek perbankan syariah ini, tampak bahwa penyelesaian permasalahan hukum tidak cukup hanya diselesaikan dengan aturan semata, perlu upaya sinergisitas antara struktur penegak hukum dan lembaga hukumnya, substansi dan budaya hukumnya. Dalam hal ini penerapan budaya hukum tercermin dari penerapan nilai-nilai yang dikehendaki para pihak dalam hal ini Putusan Mahkaham Konsitusi memutuskan untuk menghapuskan bagian penjelasan Pasal 55 UU Perbankan Syariah demi keadilan dan penyelesaian berdasarkan interpretasi history bahwa kompetensi penyelesaian sengketa hukum ekonomi syariah ada pada Pengadilan Agama. ${ }^{26}$

Bahwa penerapan hukum progresif, belum dapat memberikan rasa keadilan bagi sebagian masyarakat karena dalam hukum progresif terdapat kelemahan yang tentunya harus dicarikan solusi dan penyempurnaan untuk perbaikan di masa yang akan datang. Dalam penerapannya, hukum progresif juga tetap berlandaskan pada hukum yang ada. Namun dalam hal ini hokum yang dimaknai secara luas. Bahkan memperhatikan nilai-nilai yang berkembang dalam masyarakat yang dapat digali pula dari nilai-nilai dalam sila-sila Pancasila. Dalam penerapannya juga diperlukan keberanian dan kecerdasan serta kearifan bagi pihak yang akan mengambil keputusannya dan menetapkannya. Bahwa dalam penyelesaian sengketa perbankan syariah, yang digunakan bukan saja perjanjian (akad syariah) yang ada, namun politik hukum, sosiologi hukum, filsafat hokum bahkan psikologi hukum juga diterapkan dalam rangka memberikan jawaban atas permasalahan yang dihadapi masyarakat pemerhati dan peminat hukum ekonomi syariah. ${ }^{27}$

Turiman, berdasarkan konsep paradigma pancasila berthawaf menjelaskan, bahwa Sila Ke satu menjadi nur cahaya yang menyinari keempat sila lainnya, yaitu Ketuhanan Yang Maha Esa, sebagai yang mewakili "God Spot" titik Tuhan/Kecerdasan Spiritual (Spiritual Quentient (SQ), menerangi Manusia yang berprikemanusian yang. Spiritual Quentient (SQ) merupakan kemampuan manusia dalam memahami arti (meaning) dan nilai (value) terbaik dalam kehidupan serta tujuan (vision) yang mendasar terhadap hal-hal dalam hidup dan kehidupan manusia sebagai khalifah di bumi. Spiritual Quentient (SQ) menjawab pertanyaan paling mendasar: "Siapa saya"?. "Untuk apa saya dilahirkan?" dan"Mau kemana saya setelah dilahirkan kedunia ini?" adil dan beradab sebagai yang mewakili kecerdasan pancaindra/Artificial Quentient $(A Q) .{ }^{28}$ Bagi manusia-manusia yang menempati negara yang dinamakan negara kebangsaan Indonesia yang menjunjung persatuan, yaitu Persatuan Indone-sia, sebagai yang mewakili Kecerdasan Intelektual/Intelectual Quentient (IQ), dalam bingkai kerakyatan yang dipimpin oleh hikmat kebijaksanaan dalam permusyawaratan/

${ }^{26}$ Esmi Warassih, "Pranata Hukum Sebuah Telaah Sosiologis", Semarang: PT. Suryandaru Utama, 2015, hlm. 71

27 Zuhdan Arif Fakrullah, disusunoleh Satya Arinanto dan Ninuk Triyanti, "Memahami Hukum dari Konstruksi sampai Implementasi" , Jakarta: Rajawali Pers, 2015, hlm. 23-31.

28 Turiman, "Memahami Hukum Progresif Prof. Satjipto Rahardjo dalam Paradigma "Thawaf" (Sebuah Kontemplasi Bagaimana Mewujudkan Teori Hukum Yang Membumi/Grouded Theory Meng-Indo-nesia", Artikel, Semarang: Program Doktor Ilmu Hukum UNDIP, 2010, hlm. 37. 
Volume 14, Nomor 2, Juli-Desember 2019

perwakilan sebagai yang mewakili kecerdasan emosional/Emotional Quentient $(E Q)$. Dalam mewujudkan keadilan sosial bagi seluruh rakyat Indonesia sebagai bentuk kecerdasan kreatifitas atau Creatifitas Quentient $(C Q)$, sehingga saat menterjemahkan isi yang ada dalam peraturan dan perundang-undangan yang ada dan tidak dibenarkan bertentangan dengan nilainilai Pancasila sebagai falsafah, nilai Ketuhanan dan keluhuran, kemanusian, persatuan, kerakyatan dan keadilan. ${ }^{29}$

\section{Perbandingan Relevansi Pemikiran Hans Kelsen tentang Konsep Hukum Progresif dalam menyelesaikan sengketa keuangan syariah.}

Berdasarkan uraian di atas menyebutkan bahwa paradigma interpretif atau konstruktivisme boleh disebut sebagai penyangkalan terhadap paradigma positivism. Oleh karena itulah paradigm konstruktivisme dipilih dalam pembahasan ini. Teori Hans Kelsen yang menyebutkan hukum itu harus murni dari elemen-elemen asing yang tidak yuridis. Seharusnya direkonstruksi untuk memenuhi harapan masyarakat dan bekerjanaya hukum untuk masyarakat dalam menyelesaikan masalahnya. ${ }^{30}$

Pemahaman tentang kebenaran dan realitas yang bersifat relatif merupakan teori konstruktivisme, teori ini berlaku sesuai dengan konteks dan spesifik yang relevan dengan prilaku sosial masyarakat. Teori konstruktivisme pada dasarnya menolak teori generalisasi yang berupaya menghasilkan deskripsi yang ganjil. Paradigma kostruktivisme berasal dari keyakinan tentang realitas ada dan bermacam-macam. Keberadaan teori Realitas merupakan keberagaman konstruksi mental yang sifatnya subjektif ada dalam diri manusi (masyarakat), yang berdasarkan pada pengalaman sosial, agama, budaya, sistem nilai-nilai lainnya dan bersifat relatif. Sehingga dalam pemahaman paradigma interpretif atau konstruktivisme, realitas yang ada pada saat itu dianalisa sehingga tidak bisa digeneralisasikan. ${ }^{31}$

Relevansi pemikiran Hans Kelsen tentang hukum bagi pembangunan konsep hukum progresif adalah dalam rangka melengkapi dan menyempurnakan bekerjanya hukum di masyrakat. Agar tewujud keseimbangan atau harmonisasi antara das sollen dan das sein. ${ }^{32}$ Dalam hal ini, pembangunan konsep hukum progresif tetap memerlukan kontrol dari pemikiran Hans Kelsen tentang Teori Hukum Murni. Bahwa bekerjanya hukum itu dapat keluar dari hukum, asas atau normanya ("rule breaking"). Namun dalam implementasinya tetap memperhatikan hukum yang sudah ada. Dalam hal ini pengertian hukum dalam arti luas. Prioritas yang digunakan sedagai pedoman adalah peraturan perundang-undangan dan hukum adat sesuai dengan permasalahan yang dihadapi. Bahwa dalam implementasinya hukum progresif masih terdapat kelemahan dari aspek manusianya, oleh karena itu sinergi

${ }^{29}$ Ibid, hlm. 38.

${ }^{30}$ Hans Kelsen B, Op. Cit, hlm. 5.

${ }^{31}$ Zuhdan Arif Fakrullah, disusunoleh Satya Arinanto dan Ninuk Triyanti, "Memahami Hukum dari Konstruksi sampai Implementasi”, Jakarta: Rajawali Pers, 2015, hlm. 93.

${ }^{32}$ Hans Kelsen B, Op. Cit, hlm. 73-77. 
penerapan hukum dengan memperhatikan nilai yang berlaku di antara para pihak dan kemampuan yang mencakup 5 (lima) kecerdasan yaitu SQ, AQ, IQ, EQ dan CQ. ${ }^{33}$

\section{Solusi Teori Hukum Progresif Hans Kelsen dan Satjipto Raharjo dalam Penyelesaian Sengketa Keuangan Syariah}

Berdasarkan Pasal 49 huruf (i) UU 3/2006 tentang kekuasaan kehakiman, maka penyelesaian sengketa keuangan syariah secara litigasi dilakukan oleh Pengadilan Agama. Adapun penyelesaian sengketa keuangan syariah secara nonlitigasi dapat dilakukan melalui Arbitrase atau Alternatif Penyelesaian Sengketa yang meliputi konsultasi, negosiasi, mediasi, konsiliasi atau penilaian ahli sebagaimana diatur UU 30/1999. Oleh karena keuangan syariah berjalan berdasarkan prinsip syariah, maka lembaga arbitrase yang digunakan adalah Badan Arbitrase Syariah Nasional (BASYARNAS). Dalam rangka mendukung penguatan kerangka hukum dalam pengembangan pasar modal syariah, perlu dibentuk satu regulasi khusus berupa undangundang keuangan syariah yang di dalamnya mengatur secara komprehensif dari ketentuan umum hingga penyelesaian sengketa dengan memberikan kewenangan kepada Pengadilan Agama dalam penyelesaian sengketa secara litigasi. Dalam regulasi tersebut juga diatur mengenai penyelesaian sengketa keuangan syariah secara non-litigasi dengan memberikan kewenangan kepada Badan Arbitrase Syariah Nasional (BASYARNAS) sebagai lembaga penyelesai sengketanya. Dengan demikian, persoalan kekosongan hukum mengenai penyelesaian sengketa keuangan syariah mendapat kepastian hukum, inilah yang disebut dengan win win solusion, sebagai bentuk aplikasi solusi teori hukum progresif dalam menyelesaikan sengketa keuangan syariah.

\section{Penutup}

Berdasarkan analisis di atas maka kesimpulannya bahwa penyelesaian sengketa keuangan syariah dalam perspektif hukum progresif relevan dengan pemikiran Hans Kelsen tentang hukum bagi pembangunan konsep hukum progresif yaitu dalam rangka melengkapi dan menyempurnakan bekerjanya hukum di masyarakat. Agar tewujud keseimbangan atau harmonisasi antara das sollen dan das sein. Dalam hal ini, pembangunan konsep hukum progresif tetap memerlukan control dari pemikiran Hans Kelsen tentang Teoori Hukum Murni. Bahwa bekerjanya hukum itu dapat keluar dari hukum, asas atau normanya ("rule breaking"). Namun dalam implementasinya tetap memperhatikan hukum yang sudah ada. Dalam hal ini pengertian hukum dalam arti luas. Prioritas yang digunakan sedagai pedoman adalah peraturan perundang-undangan dan hukum adat sesuai dengan permasalahan yang dihadapi. Bahwa dalam implementasinya hukum progresif masih terdapat kelemahan dari aspek manusianya, oleh karena itu sinergi penerapan hukum dengan memperhatikan nilai

${ }^{33}$ Turiman, Op. Cit, hlm. 37-38. 
Volume 14, Nomor 2, Juli-Desember 2019

yang berlaku di antara para pihak dalam hal ini dapat digali dari nilai-nilai yang terkandung dalam sila-sila Pancasila dan kemampuan yang mencakup 5 (lima) kecerdasan yaitu SQ, AQ, IQ, EQ dan CQ. Penyelesaian sengketa keuangan syariah dalam teori hukum progresif melalui dua cara, dengan litigasi dan non litigasi.

\section{Daftar Pustaka}

Adji Samekto, "Ilmu Hukum Dalam Perkembangan Pemikiran Menuju PostModernisme", Lampung: Indepth Publishing, 2012.

Adji Samekto, "Hukum Dalam Lintasan Sejarah", Bandar Lampung: Indepth Publishing, 2013.

Anonimus, "Teori Hukum Murni (The Pure Theory Of Law', http://mknunsri.blogspot.com/2010/03/teori-hukum-murni-pure-theory-of-law.html, diakses tanggal 29 November 2015.

Darji Darmodiharjo dan Shidarta, 'Pokok-Pokok Filsafat Hukum', Jakarta: Gramedia Pustaka Utama, 2014.

Denzindan Lincoln dalam Erlyn Indarti, "Pidato Pengukuhan Guru Besar: Diskresidan Paradigma Sebuah Telaah Filsafat Hukum", Semarang: Fakultas Hukum Universitas Diponegoro, 2010.

Esmi Warassih, 'Pranata Hukum Sebuah Telaah Sosiologis', Semarang: PT. Suryandaru Utama, 2015.

Edi Hudiata, Rekonstruksi Hukum Penyelesaian Sengketa Pasar Modal Syariah: Penguatan Aspek Regulasi Untuk Memberikan Kepastian Hukum, Jurnal Hukum dan Peradilan, Volume 6 Nomor 2, Juli 2017.

Guba, E.G. dalam Norman K. Denzindan Y.S. Lincoln, "Handbook of Qualitatif Research,Edisi Bahasa Indonesia", Yogyakarta: Pustaka Pelajar, 2015.

Hans Kelsen A, "Pengantar Teori Hukum", Penerjemah: Siwi Purwadi, Bandung: Nusa Media, 2015.

Hans Kelsen B, “Teori Hukum Murni" , Penerjemah: Raisul Muttaqin, Bandung: Nusa Media, 2015.

Noer Jameel, "Hakim Progresif, Mengurai Benang Kusut Ketidak tertiban Masyarakat di Indonesia", Academia.edu. 2014. 
Volume 14, Nomor 2, Juli-Desember 2019

Rikardo Simarmata, "Socio-Legal Studies dan Gerakan Pembaharauan Hukum dalam Digest Law", Society and Development, Volume 1 Desember 2006-Maret 2007.

Robert B. Seidman dalam Turiman, "Memahami Hukum Progresif Prof. Satjipto Rahardjo Dalam Paradigma "Thawaf" (Sebuah Kontemplasi Bagaimana Mewujudkan Teori Hukum Yang Membumi/Grouded Theory Meng-Indonesia", Artikel, Semarang: Program Doktor Ilmu Hukum UNDIP, 2010.

Satjipto Rahardjo, "Hukum Progresif, Aksi, Bukan Teks", Kumpulan Tulisan Pada Ulang Tahun ke-40

Suryati Dzuluqy, Penyelesaian Sengketa Ekonomi Syariah Secara Litigasi, Ptabandung.go.id, 2019.

Zuhdan Arif Fakrullah, disusunoleh Satya Arinantodan Ninuk Triyanti, "Memahami Hukum dari Konstruksi sampai Implementasi”, Jakarta: Rajawali Pers, 2015.

SudiknoMertokusumo, “TeoriHukum" , Yogyakarta: Cahaya Atma Pustaka, 2012.

Turiman, "Memahami Hukum Progresif Prof. Satjipto Rahardjo Dalam Paradigma "Thawaf" (Sebuah Kontemplasi Bagaimana Mewujudkan Teori Hukum Yang Membumi/Grouded Theory Meng-Indo-nesia", Artikel Semarang: Program Doktor Ilmu Hukum UNDIP, 2010.

Nurhadi, "Perspektif Hukum Progresif Dalam Menyelesaian Sengketa Perbankan Syariah", Pascasarjana Uiversitas Islam Riau Prodi Ilmu Hukum Riau, 2016. 